\title{
Perspective
}

An occasional series in which contributors refiect on their careers and interests in poychiatry

\section{Looking Back at Psychiatry in General Practice}

\author{
ARthur Watts
}

\begin{abstract}
As students at the Durham medical school in Newcastle during the early thirties, we were taught that illness could be due to certain factors and these were listed. The malady could be caused by infection, acute or chronic, trauma, neoplasia .... there were many possibilities but at the very end was a sort of garbage bin for all the diseases which did not fit neatly into the organic syndromes; these
\end{abstract}

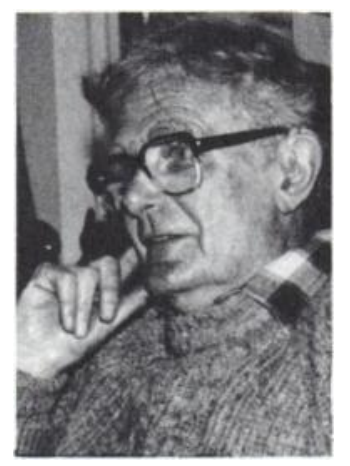
were called hysteria or psychoneurosis. These functional cases were diagnosed in a purely negative way, by a process of exclusion. No attempt was made to explain possible reasons for these troubles and there were no suggestions as to how to treat them. We were led to believe that such people were no more than time-wasters, suffering from unworthy maladies. If neurosis in all its forms gave rise to disdain, psychosis produced overt panic, as exemplified in the following case history. A young woman of 20 was admitted to a medical ward in the late stages of pregnancy because she was suffering from severe Sydenham's chorea. She was so bad, she was constantly in danger of falling out of bed and she was quite unable to speak coherently. It must have been because of this she was deemed mad, and a respectable medical ward was certainly no place for a lunatic. Fear in both the medical and nursing staff had completely obliterated all feelings of compassion. She was certified and transferred to the asylum where she died the next day. It was well known that chorea gravis carried with it a bad prognosis and, after all, there were side wards. The poor lass should have been allowed to die in dignity in one of them.

Psychiatry was one of the six so-called minor subjects we had to pass at finals. To cover the syllabus we attended a short course of lectures in Cox Lodge asylum (now St Nicholas Hospital, Gosforth) given by Dr Hector MacPhail. We had to be admitted through locked doors and walk along corridors reeking of stale food, corduroy trousers and carbolic soap; it was all rather an unnerving experience. We were shown advanced cases of depression, mania and all the schizophrenic syndromes, and of course cases of General Paralysis of the Insane. This was notable as it was the only mental illness for which there was any active treatment. This consisted of giving the patient periodic attacks of malaria. This fever treatment made some doctors clutch at straws. Our practice notes recorded that about that time one of our patients, who suffered from periodic attacks of a schizo-affective disorder, was prescribed a twice weekly injection of TAB vaccine in the vain hope that the feverish reaction it caused would have some beneficial effect. The plain fact was that in those days there was nothing to be done for the psychotic patient beyond custodial care. We were shown padded cells, some of which contained a cowering patient clad in a crude rip-proof shirt. We were given a demonstration on how to apply a straitjacket. Rightly or wrongly we got the impression that by far the most important thing to learn from our course on psychiatry was how to fill in a form correctly, for the certification of a lunatic.

When I became a houseman I had the good fortune to work for Dr Horsely Drummond, who has been described by Dr Hewan Dewar as the initiator of psychiatry into the Royal Victoria Infirmary (RVI) at Newcastle. I was aware of his interest in the subject as from time to time he used a Corrigan's button. This was a small cautery which was heated in front of the patient and then applied with suitable ritual to the affected area of the hysteric, and not surprisingly it sometimes produced a dramatic reaction. I was not impressed by this measure but I realised that Horsely Drummond was a very kindly and caring physician. Alone among the senior staff of the hospital, he visited his patients every day and he was prepared to admit a few psychoneurotics to his ward. Dr Dewar ${ }^{1}$ told me that at times the old doctor used to borrow sister's room so that he could spend half an hour talking to such patients. Some of Horsely Drummond's caring attitude may well have rubbed off on me, I certainly had a great admiration for him.

Once in general practice I was soon made well aware that psychoneurosis was by no means a rarity. Many attended the new young doctor hoping in him to find the help they had failed to get from the principal, who usually had the same attitude of rejection as had the consultants at the RVI. These people were looked upon as a nuisance and they were fobbed off with nauseous mixtures of bromide, valerian or 
gentian. There were a few exceptions to this rule, and as an assistant in Peterborough I came across Dr Alec Watt who took an active interest in this type of patient. He was not a bit popular with the other GPs who labelled him as a crank and, what was far worse, they accused him of trying to poach patients. He later abandoned general practice for psychiatry which he practised in Sussex. I was both worried and baffled by these cases. They were quite different from patients who suffered from some genuine organic illness. They kept on asking awkward questions as to what was causing the symptoms and, ro matter what one said or did, one was left with a gut feeling that they had gone away dissatisfied. This sense of inadequacy was so bad that one's spirits fell as the neurotic entered the consulting room. I did notice one curious thing about these people and that was that all psychoneurotic symptoms disappeared if a genuine organic illness intervened, but unfortunately the neurosis was resurrected once the pneumonia had cleared or the inflamed appendix had been removed.

Psychosis remained as frightening as ever; one felt baffled and impotent to help. As a locum in the village of Sedgefield, County Durham, I was called in by the police to see an old woman of the practice who had been found wandering about in the fields naked. I saw her at the station; she had been discreetly covered with a blanket but she was restless and jabbering away to herself. I had no idea how to start any consultation; my main preoccupation was whether I could remember how to complete the certification form as I tried to think where the principal would have left them. I was lucky. Sedgefield had the county asylum and the police, detecting my embarrassment, suggested that I got in touch with one of the staff there. I did this and a psychiatrist came along and completed the necessary admission form.

In those days I had a complete blind spot as regards depression. I had heard about melancholia, and Hector MacPhail had showed us cases of a woman who could not stop weeping and an old man verging on a stupor. When a man came to see me complaining of constipation I gave him a good physical examination; I even referred him for a bowel X-Ray which was negative. Once I had the hosptial report I saw my patient, I gave him a clean bill of health and told him he had nothing to worry about. He went straight home and put his head in the gas oven. Even when I heard the news, it never dawned on me that I had missed a classical case of depression; indeed I felt rather indignant that he hadn't believed me.

Anxiety when it was associated with some frank physical disease was easier to cope with. While examining the chest of a man with some infection I found that he had a loud systolic murmur and I spent some time listening to it. I decided it was benign and of no consequence. The man asked me why I had spent so much time listening to his heart and I told him what I had found. Both he and his wife were well aware of the murmur and were scared stiff of its significance. They had never dared to discuss it before but both felt that he could drop dead at any minute. Once his chest infection had cleared I referred him to a cardiologist who confirmed my ideas and, when I told the pair, they were both well satisfied with my reassurance. Such cases were very rare in practice but I can remember the deep satisfaction I felt at being able to relieve the anxiety of two people.

When the war broke out I was in South Africa and I joined the medical corps in 1940. While in the army there was a call for volunteers to do a crash course on psychiatry. I jumped at the idea. I felt that this would equip me to be a better GP once the war was over. I had no ambitions to become a psychiatrist. The course lasted for some six weeks and then I did a year in a neuropsychiatric unit which was well supplied with hot psychiatric cases, most of them young people. It was a wonderful clinical experience. My main mentor was Major Alice Cox, a Glasgow graduate, and a contemporary of Professor R. D. Gillespie. I learned how to recognise the various psychiatric syndromes and I soon lost my dread of mental illness. I gave ECT and I watched over patients in insulin coma. I had plenty of time to develop a technique in psychotherapy, with experts on tap if I ran into any difficulty. I read voraciously. There were two Freudian analysts on the staff, and I was led to believe that if only one submitted to a full course of Freudian analysis, one would become secure, mature and a thoroughly balanced individual for the rest of one's life. This illusion was rudely shattered when one of these teachers developed an acute depression and managed to shoot himself. I continued to have faith in a more eclectic approach to psychotherapy. I learned to listen to people and attempted to interpret their behaviour. Recoveries were slow and this I put down to my inexperience. However, the net result was that once the war was over and I returned to general practice in Britain, I felt far better equipped to cope with psychiatric problems.

At first I was almost overwhelmed by the work. I started morning surgery an hour before the scheduled time so that I could see psychiatric patients. Others were fitted in at the end of the day. I didn't see patients outside the practice, and this in a way limited my case load, and I was just able to cope. I was amazed at the number of cases of endogenous depression I saw. I began to feel that I was over-diagnosing the condition, but, with every case I passed on to a psychiatrist, the label was confirmed. I found myself in the unenviable postion of being able to diagnose the condition, but unable to treat the majority of cases; ECT was only available to patients who were ill enough to be admitted to the local mental hospital. All but the very sick refused to take such a step as there was still much stigma and dread attached to such an institution. After a meeting of psychiatrists in the area I wrote a letter pleading for an out-patient clinic to be opened at the Leicester Royal Infirmary, with facilities for ECT in suitable cases. The answer I received showed a complete lack of appreciation of life in the community and my motives were misinterpreted. The expert who replied took the greatest exception to my attitude regarding mental illness. He told me that my ostrich-like method of trying to hide mental illness was one that had gradually and firmly been eroded by all that had the best interests of the patient at heart. I was paranoid for a week after receiving that letter and I never did reply to it. Dr John 
Pearce came to my rescue when he set up rooms in Leicester. There he saw some of my patients privately and, when necessary, ECT was given. His support and encouragement were a great help to me. Apart from the few who could afford such private treatment, the patients with a severe depression came off best as they were able to get all the treatment they needed at the local mental hospital but they amounted to only about one-eighth of the cases diagnosed. The majority of patients opted to stay at home and these had to be seen regularly and they were supported by repeated reassurance that the phase of misery would pass. It was a dreary business and seemed rather futile but, once the depression had passed, a number of those patients told me how much my words of hope had comforted them. Any active treatment was purely symptomatic. Barbiturates were given to relieve insomnia, and I was lucky in that only one of my patients killed himself with an over-dose. Amphetamine was tried to boost energy, but it was disappointing. A few did benefit from Drinamyl tablets, a mixture of barbiturate and amphetamine. The danger here was that patients were prone to become addicted to the tablets which later became known as purple hearts, and as such were in great demand by the drug traffickers of those days. Supporting depressed patients was a wearisome business and the illness lasted for a long time, the average duration of an untreated depression was about 11 months.

The following case completely convinced me of the efficacy of ECT when given to an appropriate patient. One Monday morning I was called to see a small girl who had appendicitis. She had been ill from the Saturday but her mother did not want to trouble the doctor at the weekend. The child was referred to hospital but she had already developed peritonitis and she died. The mother became very depressed as she blamed herself for what had happened. She told me that she could never forgive herself as long as she lived. I had many sessions with her. I agreed that she had made a mistake, but pointed out that we all do stupid things from time to time and get away with it on most occasions. She had been unlucky. No amount of talking helped her and then at one session she told me that she was beginning to hate her other children as they reminded her of the one she had lost. I suggested that she should go to hospital and have some ECT and to this she agreed. I saw her a few weeks later after she had had some six shocks, and she was a different woman. She said that now she realised that while she had done wrong, the tragedy no longer obsessed and depressed her all day long. She could think of other things and was leading a normal life. She added in conclusion that she had absolutely no faith in the treatment. She had only agreed to take it because I had been so kind to her. Double blind trials are not the only way of proving the efficacy of treatment. This case convinced me beyond all doubt that ECT was not just a brutal type of placebo or the modern equivalent of Corrigan's button.

In the early stages of an endogenous depression, especially if it was the first attack, it was very difficult to differentiate between an anxiety state and a primary depression. As the years passed it was borne in on me that a number of cases which had been diagnosed as anxiety states, and had been successfully treated by way of psychotherapy, turned up later as typical cases of endogenous depression. I then realised my clever 'cure' had been in fact a natural remission from melancholia. There were cases that certainly did benefit from psychotherapy but gradually I came to the conclusion that if there was no response to the treatment after six sessions, more were likely to be a waste of time. Some of these therapeutic failures I referred to a psychiatrist, but psychotherapy in any form was in short supply in our area, and long-term treatment of this kind was virtually unobtainable. About 1959 things became a lot easier for me. Geigy Pharmaceuticals sent me a huge consignment of imipramine tablets to try out on my depressed patients and the results were most gratifying. I could now give active treatment to any depressed patients and a number of chronic cases were vastly improved on this treatment. Such people found they were able to undertake activities that had long been abandoned. Those were exciting days. At last the GP had tools with which he could treat his depressed patients. These new drugs were so effective that, when benzodiazepines appeared, and I was assured by the drug firms that what imipramine and allied agents had done for depression these new drugs did for anxiety, I was foolish enough to swallow this propaganda. It was true, anxious patients did seem better and they felt the drugs had helped them. From my point of view it was far easier to give a prescription for librium than spend time on psychotherapy. It was only when at some medical meeting it was suggested that it would be easier for all concerned to have librium added to the tap water that I realised how liberal had been my prescriptions, and how misled I had been. By then I had a number of addicts on my hands.

Anti-depressant drugs and even ECT did not relieve all cases of depression. I found there was always a hard core of both depressed and psychoneurotic patients that I wasn't able to help and the psychiatrists to whom I referred such patients were equally impotent to raise the depression or give relief. These unhappy people, and their families, had to be supported and this task was easier to perform once I had learned to tolerate them using quite a simple technique. I would make such a patient welcome by saying how nice it was to see her again. After listening to her complaints for a short time, I would say what a remarkable person she was to carry on so well with such a burden. Finally I would tell her she had to see me again. and I would make the appointment as far ahead as possible. Such patients seemed pleased to accept this exhibition of interest and concern, and they left more secure by the prospect of a further appointment, without having to request one de novo. The pre-arranged appointment meant they had not been rejected and made them feel that they were not bothering the doctor needlessly. From my point, I was saved from a feeling of irritation at their appearance; I no longer had a sinking sensation when they came into my room.

Looking back over the years, it seems obvious that any clinician, no matter what his specialty, who hopes to do his work efficiently, must be equipped to tackle the emotional 
side of the problem that confronts him. This will mean a few minutes must be spent in explaining what is wrong, and what steps are to be taken to help the patient. The doctor should be as reassuring as the case will allow. The French aphorism sums it all up. 'Guerir quelquefois, soulager souvent, consoler toujours.' Finally, the patient should be asked if he has any other questions. The overall results of treating the whole patient, the emotional as well as the physical side of the problem, give the greatest satisfaction to all concerned.

\section{RERERENCE}

'Dewar, H. A. (1986) Personal Communication.

\title{
The Wisdom of Deterrence-a Reply to Jim Dyer
}

\author{
IAN J. Deary, Lecturer in Psychology, University of Edinburgh, 7 George Square, Edinburgh
}

Dr Dyer's attack on the policy of deterrence 'The Psychopathology of Nuclear War' Bulletin, January $1986^{1}$ leaves me confused. The claim of the Medical Campaign against Nuclear Weapons (MCANW), of which Dr Dyer is a prominent member, was that it would study and disseminate information on the medical effects of nuclear war and the effects of possessing nuclear weapons, but Dr Dyer's treatment of deterrence was neither of these: it was a series of criticisms of a defence policy. The policy of deterrence has kept the peace in Europe for $\mathbf{4 0}$ years and has been supported by every British government since the end of the 1940s. It is still supported by the majority of the British electorate. Still, this does not prevent Dr Dyer from dubbing it, 'nuclear madness' which calls for the 'restoration of sanity.' Elsewhere deterrence is called a 'degenerative state' and I have to assume that the author agrees with the following quote as he cites it without criticism: 'nuclear weapons constitute the greatest immediate threat to the health and welfare of mankind.'

Even if we allow Dr Dyer the luxury of 40 years of immediacy then the three most immediate threats to the health and welfare of mankind during that time have been famine/overpopulation, Stalinism and conventional warfare (150 wars, none in Europe, have been fought since World War II with the loss of over $10,000,000$ lives). In support of the claim that nuclear weapons are the greatest immediate threat to the health and welfare of mankind from now on we might have expected a detailed consideration of the following three possibilities:

1. The money spent on nuclear weapons is money that would be spent on bettering the lot of man if we got rid of those weapons.

2. Deterrence is a system that is more dangerous than a given system $X$. This possibility would require a detailed discussion of how we would get to system $X$ from our deterrence system and why we have not done so.
3. Deterrence is an irrational system, not merely an unpredictable one.

Although they are not included in Dr Dyer's account there are those (e.g. Sidel ${ }^{2}$ ) who have argued that the nuclear build-up has contributed to global famine and to the lack of medical aid being directed to the Third World. These commentators, though, do not appear to have considered the following points.

1. The problem with nuclear weapons is not that they are ruinously expensive. As Steven Walt ${ }^{3}$ has said, 'compared with other armaments, nuclear weapons are small, light, cheap and extremely destructive.' Dyer's claim that, 'One Pershing missile costs $\$ 5$ million, the cost of immunising one million Third World children against preventable infectious diseases,' misses the point.

2. Most, and all British, promises of nuclear reduction are backed up by a second promise of an increase in conventional strength. In Britain that would mean two things. First, at a conservative estimate, the defence budget would triple. (The Labour Party in Britain have already stated that if they win the next election and attempt to carry out their defence policies they have no prospect of cutting defence expenditure-Sunday Times, 30 March 1986.) Second, the only realistic way to boost defences to pre-disarmament levels would be to bring back conscription. I have never heard those who ask for nuclear weapons to be replaced by increased conventional strength mention this: I wonder why?

3. Calls for nuclear disarmament on the grounds of cost are odd when one knows that nuclear weapons only take $10 \%$ of the British defence budget. It is conventional weapons that threaten the foreign aid budget, not nuclear weapons. 